\title{
Ginkgolide B inhibits platelet and monocyte adhesion in TNFa-treated HUVECs under laminar shear stress
}

\author{
Ming Zhang ${ }^{1,2 \dagger}$, Jie Sun ${ }^{1 \dagger}$, Beidong Chen ${ }^{1}$, Yanyang Zhao ${ }^{1}$, Huan Gong ${ }^{1}$, Yun You ${ }^{3}$ and Ruomei Qi ${ }^{1,2^{*}}$ (D)
}

\begin{abstract}
Background: Endothelial cells are sensitive to changes in both blood components and mechanical stimuli. Endothelial cells may undergo phenotypic changes, such as changes in adhesion protein expression, under different shear stress conditions. Such changes may impact platelet and monocyte adhesion to endothelial cells. This phenomenon is linked to chronic vascular inflammation and the development of atherosclerosis. In the present study, we investigated the effects of ginkgolide B on platelet and monocyte adhesion to human umbilical vein endothelial cells (HUVECS) under different conditions of laminar shear stress.

Methods: Platelet and monocyte adhesion to endothelial cells was determined by the Bioflux 1000. HUVECs were incubated with ginkgolide B or aspirin for $12 \mathrm{~h}$, and then TNFa was added for $2 \mathrm{~h}$ to induce the inflammatory response under conditions of 1 and $9 \mathrm{dyn} / \mathrm{cm}^{2}$ laminar shear stress. The protein expression was analyzed by Western blot.
\end{abstract}

Results: The number of platelets that adhered was greater under conditions of $1 \mathrm{dyn} / \mathrm{cm}^{2}$ than under conditions of $9 \mathrm{dyn} / \mathrm{cm}^{2}$ of laminar shear stress (74.8 19.2 and $59.5 \pm 15.1$, respectively). Ginkgolide B reduced the tumor necrosis factor a (TNFa)-induced increase in platelet and monocyte adhesion to HUVECs at 1 and $9 \mathrm{dyn} / \mathrm{cm}^{2}$ of laminar shear stress. In TNFa-treated HUVECs, the number of monocytes that adhered was greater under conditions of $1 \mathrm{dyn} / \mathrm{cm}^{2}$ of laminar shear stress compared with $9 \mathrm{dyn} / \mathrm{cm}^{2}$ (29.1 \pm 4.9 and $22.7 \pm 3.7$, respectively). Ginkgolide B inhibited the TNFa-induced expression of vascular cell adhesion molecule-1(VCAM-1), VE-cadherin, and Cx43 in HUVECS at 1 and $9 \mathrm{dyn} / \mathrm{cm}^{2}$. The expression of these proteins was not different between 1 and $9 \mathrm{dyn} / \mathrm{cm}^{2}$.

Conclusions: Ginkgolide B suppressed platelet and monocyte adhesion under different conditions of laminar shear stress. Moreover, ginkgolide B reduced VCAM-1, VE-cadherin and Cx43 expression in TNFa-treated HUVECs under laminar shear stress. This suggested that ginkgolide B might shed light on the treatment of inflammation in atherosclerosis.

Keywords: Ginkgolide B, Endothelial cells, Platelets, VCAM-1, VE-cadherin, Shear stress

\section{Background}

Endothelial cells are the initial barriers on the vessel wall. Endothelial cell dysfunction is a primary cause of cardiovascular disease. Endothelial cells are sensitive to changes in both blood components and mechanical

\footnotetext{
* Correspondence: ruomeiqi@163.com

${ }^{\dagger}$ Ming Zhang and Jie Sun contributed equally to this work.

${ }^{1} \mathrm{MOH}$ Key Laboratory of Geriatrics, Beijing Hospital, National Center of Gerontology, Beijing, China

${ }^{2}$ Graduate School of Peking Union Medical College, Chinese Academy of

Medical Sciences, Beijing, China

Full list of author information is available at the end of the article
}

stimuli [1-3]. In humans, normal physiological flow ranges from 10 to $50 \mathrm{dyn} / \mathrm{cm}^{2}$ and is highly pulsatile in arteries and $\sim 10$-fold less with minimal pulsation in veins [4]. High shear stress that results from laminar flow promotes endothelial cell survival and quiescence, alignment in the direction of the flow, and the secretion of substances that promote vasodilation and anticoagulation $[5,6]$. Low shear stress or changes in the direction of shear stress, as found in turbulent flow, promotes vasoconstriction, coagulation, and platelet aggregation $[7,8]$. The precise mechanisms by which endothelial

(c) The Author(s). 2018 Open Access This article is distributed under the terms of the Creative Commons Attribution 4.0 International License (http://creativecommons.org/licenses/by/4.0/), which permits unrestricted use, distribution, and reproduction in any medium, provided you give appropriate credit to the original author(s) and the source, provide a link to the Creative Commons license, and indicate if changes were made. The Creative Commons Public Domain Dedication waiver (http://creativecommons.org/publicdomain/zero/1.0/) applies to the data made available in this article, unless otherwise stated. 
cells sense shear stress to affect cell-cell interactions are still not completely understood. Endothelial cells may undergo phenotypic changes, such as changes in adhesion protein expression, under different shear stress conditions. Such changes may impact platelet and monocyte adhesion to endothelial cells. This phenomenon is linked to chronic vascular inflammation and the development of atherosclerosis [9-11].

In the physiological state, endothelial cells maintain vessel integrity through junction proteins. VE-cadherin is a calcium-dependent cell-cell adhesion protein that is composed of five extracellular cadherin repeats and a transmembrane region [12]. VE-cadherin antibodies were shown to increase monolayer permeability in cultured cells [13]. We recently reported that VE-cadherin was involved in monocyte translocation in oxidized low-density lipoprotein (ox-LDL)-treated endothelial cells. Treatment with VE-cadherin siRNA reduced monocyte translocation in ox-LDL-treated endothelial cells [14]. Cx43 is also a junction protein that belongs to the gap junction protein family. Gap junctions play a role in intercellular communication between cells to regulate cell death, proliferation, and differentiation [15]. Gap junctions are involved in connecting adjacent cells to permit the exchange of low-molecular-weight molecules, such as ions and secondary messengers, to maintain homeostasis $[16,17]$.

Tumor necrosis factor $\alpha$ (TNF $\alpha)$ is a member of the cytokine family and involved in various inflammatory processes. TNF $\alpha$ is implicated in several human diseases, including atherosclerosis and cardiovascular disease. It is a potent inducer of nuclear factor $\mathrm{\kappa B}(\mathrm{NF}-\mathrm{kB})$ signaling, which is involved in the transcription of many inflammatory proteins. TNF $\alpha$ is also involved in endothelial cell injury under pathological conditions, such as atherosclerosis [18].

Ginkgolide B is a Ginkgo biloba leaf extract that can completely bind platelet-activating factor receptor (PAFR) and inhibit platelet activation [19]. Our recent studies showed that ginkgolide B inhibited inflammatory protein expression that was induced by ox-LDL in human umbilical vein endothelial cells (HUVECs) [20, 21]. However, remaining unknown is whether ginkgolide B inhibits platelet and monocyte adhesion to endothelial cells under different shear stress conditions. In the present study, we investigated the effects of ginkgolide B on platelet and monocytes adhesion to endothelial cells and phenotypic changes under different laminar shear stress conditions.

\section{Methods}

\section{Materials}

Ginkgolide B (95\% purity) was purchased from Daguanyuan Company (Xuzhou, Jiangsu, China). Mouse tail type I collagen were purchased from Sigma-Aldrich (St. Louis, MO, USA). Monoclonal anti-connexin 43 antibody, polyclonal anti-VCAM-1 antibody and monoclonal anti-actin antibody were purchased from Santa Cruz Biotechnology (Santa Cruz, CA, USA). Monoclonal anti-VE-cadherin antibody was purchased from Abcam (Boston, MA, USA). Bioflux 48-well plates (1-20 dyn/ $\mathrm{cm}^{-2}$; 910-0047) were purchased from Fluxion Biosciences (South San Francisco, CA, USA).

\section{Preparation of platelets}

Fresh citrate anti-coagulated venous blood was obtained from human donors who had not taken any medication for a minimum of 2 weeks before blood collection. The blood was centrifuged at $400 \times \mathrm{g}$ for $15 \mathrm{~min}$ to obtain platelet-rich plasma (PRP). The PRP was washed twice in Tyrode's/HEPES buffer with $2 \mathrm{mM}$ ethylene glycol tetraacetic acid (EGTA). Platelets were suspended in Tyrode's/HEPES buffer at a concentration of $2 \times 108$ cells/ml [22].

\section{Preparation of monocytes}

The THP-1 human monocytic cell line was obtained from the American Type Culture Collection (Manassas, VA, USA). The cells were maintained at $37{ }^{\circ} \mathrm{C}$ in RPMI 1640 medium supplemented with $10 \%$ fetal calf serum (FCS), $100 \mathrm{IU}$ penicillin, $100 \mu \mathrm{g} / \mathrm{ml}$ streptomycin, and $2 \mathrm{mM}$ L-glutamine in a humidified 5\% carbon dioxide atmosphere [23].

\section{Preparation and culture of human umbilical vein endothelial cells}

HUVECs were purchased from ScienCell Research Laboratories (Carlsbad, CA, USA). HUVECs were redissolved in a $37^{\circ} \mathrm{C}$ constant temperature water bath. The cells were cultured in M199 medium that contained 10\% fetal bovine serum (Gibco, NY, USA), $2 \mathrm{mM}$ glutamine, $100 \mathrm{U} / \mathrm{ml}$ penicillin, $100 \mu \mathrm{g} / \mathrm{ml}$ streptomycin, and $20 \mathrm{ng} /$ $\mathrm{ml}$ endothelial growth factor (R\&D, Minneapolis, $\mathrm{MN}$, USA) in an incubator at $37{ }^{\circ} \mathrm{C}$ and $5 \% \mathrm{CO}_{2}$. Cells up to passage 4 were used in the experiments [24].

\section{Platelet and monocyte adhesion to HUVECs assay}

The Bioflux 1000 system (Fluxion Biosciences Inc., CA, USA) was used in the present study. The flow experiments were performed as previously described [25]. Briefly, the microfluidic channel was coated with type I collagen $(20 \mu \mathrm{g} / \mathrm{ml})$ that was dissolved in $0.02 \mathrm{M}$ acetic acid. HUVECs $\left(3 \times 10^{7}\right)$ were seeded in microfluidic well plates until $>90 \%$ of the cells covered the well plate that was used for the experiments. HUVECs were treated with ginkgolide $B(0.6 \mathrm{mg} / \mathrm{ml})$ or aspirin $(1 \mathrm{mM})$ for $12 \mathrm{~h}$, and then TNF $\alpha$ was added for another $2 \mathrm{~h}$ under conditions of 1 and $9 \mathrm{dyn} / \mathrm{cm}^{2}$ laminar shear stress. The 
platelet suspension $\left(300 \mu \mathrm{l}, 2 \times 10^{8}\right)$ or monocyte suspension $\left(300 \mu \mathrm{l}, 5 \times 10^{6}\right)$ was added to the input channel for $45 \mathrm{~min}$ for cell adhesion under condition of $0.2 \mathrm{dyn} /$ $\mathrm{cm}^{2}$. Images were captured by a Nikon Ti100 CCD camera in five locations in the flow chamber and analyzed using Bioflux Montage software.

\section{Western blot}

HUVECs were incubated with ginkgolide B $(0.6 \mathrm{mg} / \mathrm{ml})$ or aspirin $(1 \mathrm{mM})$ for $12 \mathrm{~h}$, and then TNF $\alpha(20 \mathrm{ng} / \mathrm{ml})$ was added for $2 \mathrm{~h}$ under conditions of 1 and $9 \mathrm{dyn} / \mathrm{cm}^{2}$ laminar shear stress. The platelet or monocyte suspension was perfused for $45 \mathrm{~min}$ under condition of $0.2 \mathrm{dyn} / \mathrm{cm}^{2}$ for adhesion. After that the microfluidic channel was washed with PBS to remove unadhered platelets or monocytes for 5 min under condition of $2 \mathrm{dyn} / \mathrm{cm}^{2}$, and then lysis buffer (1\% Triton X-100, $100 \mathrm{mM}$ Tris/ $\mathrm{HCl}$ [pH 7.2], $50 \mathrm{mM} \mathrm{NaCl}, 5 \mathrm{mM}$ ethylenediaminetetraacetic acid [EDTA], $5 \mathrm{mM}$ EGTA, $1 \mu \mathrm{M}$ phenylmethylsulfonyl fluoride [PMSF], and $100 \mu \mathrm{g} / \mathrm{ml}$ leupeptin) was added. Lysates were centrifuged at 12000 $\times g$ at $4{ }^{\circ} \mathrm{C}$ for $5 \mathrm{~min}$. To obtain sufficient protein, three parallel microfluidic flow channels were used in each group. The cell lysates were separated by $10 \%$ sodium dodecyl sulfatepolyacrylamide gel electrophoresis (SDS-PAGE), and transferred to a polyvinylidene difluoride membrane (Millipore, Billerica, MA, USA. Primary antibody incubations were performed overnight at $4{ }^{\circ} \mathrm{C}$. Horseradish peroxidase-conjugated secondary antibody was applied for $1 \mathrm{~h}$ at room temperature and developed using Super Signal developing reagent (Pierce, Thermo Scientific). Blot densitometry was then performed, and the bands were analyzed using the Gene Genius Bio Imaging System.

\section{Statistical analysis}

Quantitative data are presented as mean \pm SEM. Significant differences between two groups were analyzed by two-tail unpaired Student's $t$-test. All of the calculations were performed using SPSS 18.0 software (Armonk, NY, USA). Values of $p<0.05$ were considered statistically significant.

\section{Results}

Ginkgolide B decreases platelet adhesion to TNFa-treated HUVECs under conditions of laminar shear stress

To investigate the interaction between platelets and HUVECs, platelet adhesion was determined in TNF $\alpha$-treated HUVECs under conditions of 1 and $9 \mathrm{dyn} / \mathrm{cm}^{2}$ of shear stress. Our previous studies showed that $0.6 \mathrm{mg} / \mathrm{ml}$ ginkgolide $B$ and $1 \mathrm{mM}$ aspirin significantly inhibited the inflammatory response of endothelial cells. Therefore, we applied the same doses of ginkgolide B and aspirin in the present study. As shown in Fig. 1 , at $1 \mathrm{dyn} / \mathrm{cm}^{2}$, the number of platelets that adhered was $74.8 \pm 19.2$ and $36.1 \pm 4.4$ in TNF $\alpha$-treated and -untreated HUVECs, respectively. The number of platelets that adhered was $39.5 \pm 12.3$ in ginkgolide B-treated HUVECs. We used aspirin $(1 \mathrm{mM})$ as a control. Aspirin treatment also reduced the number of platelets that adhered $(35.8 \pm 10.1)$ in TNFo-treated HUVECs. At $9 \mathrm{dyn} / \mathrm{cm}^{2}$, the number of platelets that adhered was $59.5 \pm 15.1$ and $28.8 \pm 3.7$ in TNFo-treated and -untreated HUVECs. The number of platelets that adhered was $31.5 \pm 4.9$ and $32.1 \pm 4.3$ in the ginkgolide B- and aspirin-treated groups, respectively.

\section{Ginkgolide B suppresses VCAM-1, VE-cadherin, and Cx43 expression in TNFa-treated HUVECs that present platelet adhesion under conditions of laminar shear stress}

We first investigated the effects of ginkgolide $B$ on VCAM-1 expression under laminar shear stress. As shown in Fig. 2a, at $1 \mathrm{dyn} / \mathrm{cm}^{2}, \mathrm{VCAM}-1$ expression increased by $31.7 \% \pm 2.9 \%$ in TNFo-treated HUVECs compared with the control. Ginkgolide $B$ and aspirin completely inhibited TNF $\alpha$-induced VCAM- 1 expression. VCAM-1 expression increased by $46.9 \% \pm 10.1 \%$ in TNF $\alpha$-treated HUVECs under conditions of 9 dyn $/ \mathrm{cm}^{2}$ of laminar shear stress. Ginkgolide B $(0.6 \mathrm{mg} / \mathrm{ml})$ almost completely attenuated TNF $\alpha$-induced VCAM-1 expression. Similar results were found in the aspirin-treated group.

We next evaluated the effects of ginkgolide $B$ on the expression of the tight junction proteins VE-cadherin and $\mathrm{Cx} 43$ under different conditions of laminar shear stress. As shown in Fig. 2b and c, TNF $\alpha$ treatment increased VE-cadherin expression by $31.8 \% \pm 2.2 \%$ and $38.9 \pm 9.1 \%$ under conditions of 1 and $9 \mathrm{dyn} / \mathrm{cm}^{2}$ of laminar shear stress, respectively. Ginkgolide B $(0.6 \mathrm{mg} / \mathrm{ml})$ and aspirin $(1 \mathrm{mM})$ completely abolished TNF $\alpha$-induced VE-cadherin expression at 1 and $9 \mathrm{dyn} / \mathrm{cm}^{2}$. Cx43 expression increased by $37.7 \% \pm 9.8$ and $30.5 \% \pm 6.1 \%$ in TNF $\alpha$-treated HUVECs that presented platelet adhesion at 1 and $9 \mathrm{dyn} / \mathrm{cm}^{2}$, respectively. Ginkgolide B $(0.6 \mathrm{mg} /$ $\mathrm{ml})$ and aspirin $(1 \mathrm{mM})$ significantly inhibited TNF $\alpha$-induced $\mathrm{Cx} 43$ expression at both 1 and 9 dyn/ $\mathrm{cm}^{2}$.

\section{Ginkgolide B decreases monocyte adhesion to TNFa-} treated HUVECs under conditions of laminar shear stress Furthermore, monocyte adhesion to endothelial cells was evaluated under conditions of laminar shear stress. As shown in Fig. 3a, at $1 \mathrm{dyn} / \mathrm{cm}^{2}$, the number of monocytes that adhered was $29.1 \pm 4.9$ in TNF $\alpha$-treated HUVECs. The number of monocytes that adhered was $11.3 \pm 1.9$ in the control group. At $9 \mathrm{dyn} / \mathrm{cm}^{2}$, the number of monocytes that adhered was $22.7 \pm 3.7$ in TNF $\alpha$-treated HUVECs. The number of monocytes that adhered was $14.3 \pm 4.5$ in the 


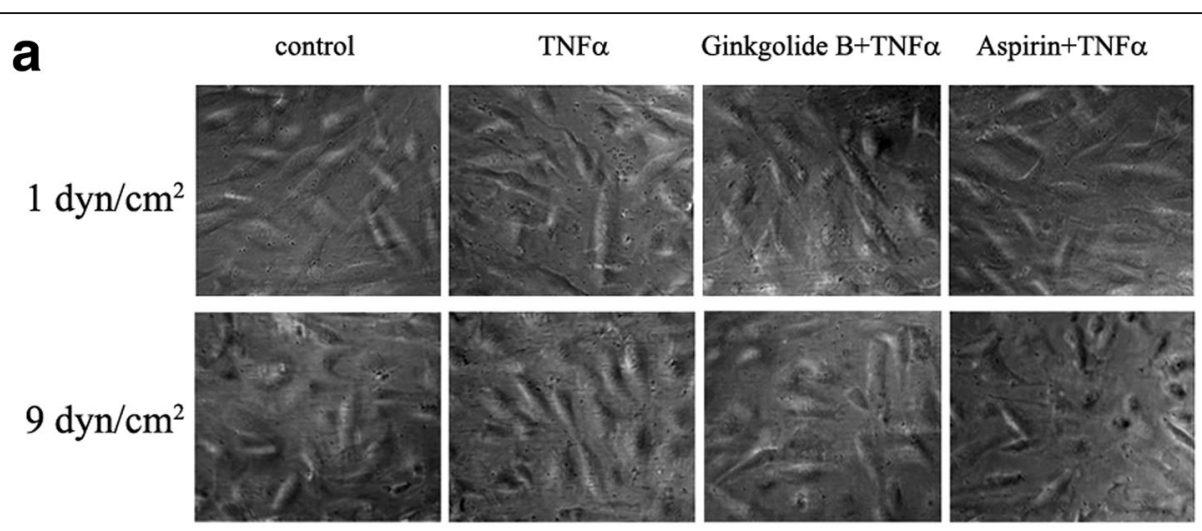

b

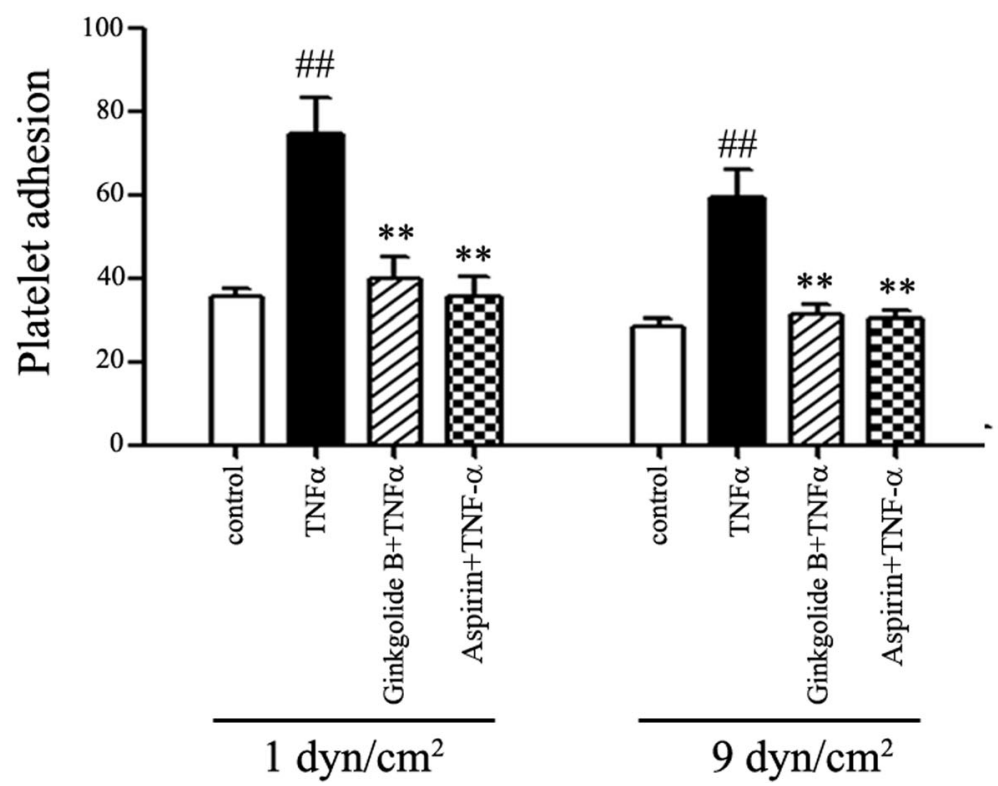

Fig. 1 Ginkgolide B reduced platelet adhesion in TNFa-treated HUVECs under different conditions of laminar shear stress. HUVECs were incubated with ginkgolide B $(0.6 \mathrm{mg} / \mathrm{ml})$ or aspirin $(1 \mathrm{mM})$ for $12 \mathrm{~h}$, and then TNFa $(20 \mathrm{ng} / \mathrm{ml})$ was added for another $2 \mathrm{~h}$. The platelet suspension was then added to the input well under conditions of 1 and $9 \mathrm{dyn} / \mathrm{cm}^{2}$ of laminar shear stress for $45 \mathrm{~min}$. The data were obtained from three independent experiments. a Ginkgolide B decreased the number of platelets that adhered to TNFa-treated HUVECs at 1 and 9 dyn/ $\mathrm{cm}^{2}$. $\mathbf{b}$ Platelet adhesion to HUVECs. ${ }^{\# \#} p<0.01$, significant difference between TNFa-treated and -untreated HUVECs. ${ }^{* *} p<0.01$, significant difference between TNFa-treated cells and ginkgolide B- and aspirin-treated cells

control group. Ginkgolide B $(0.6 \mathrm{mg} / \mathrm{ml})$ inhibited monocyte adhesion to TNF $\alpha$-treated HUVECs. The number of monocytes that adhered was $17.0 \pm 2.8$ at $1 \mathrm{dyn} / \mathrm{cm}^{2}$ and $15.7 \pm 4.8$ at $9 \mathrm{dyn} / \mathrm{cm}^{2}$. In the aspirin-treated group, the number of monocytes that adhered was $20.7 \pm 1.8$ and 14.7 \pm 5.4 at 1 and $9 \mathrm{dyn} / \mathrm{cm}^{2}$, respectively. Significant differences were found between TNF $\alpha$-treated cells and ginkgolide B- and aspirin-treated cells.

Ginkgolide B suppresses VCAM-1, VE-cadherin, and Cx43 expression in TNFa-treated HUVECs that present monocyte adhesion under conditions of laminar shear stress

We also evaluated the effects of ginkgolide B on adhesion proteins and tight junction proteins under conditions of laminar shear stress and monocyte adhesion in HUVECs. As shown in Fig. 4a-c, VCAM-1 expression increased by $29.8 \% \pm 2.9 \%$ at $1 \mathrm{dyn} / \mathrm{cm}^{2}$ and by $48.6 \% \pm 10.1 \%$ at $9 \mathrm{dyn} /$ $\mathrm{cm}^{2}$ in TNFo-treated HUVECs. Ginkgolide B inhibited TNFo-induced VCAM-1 expression at both 1 and 9 dyn/ $\mathrm{cm}^{2}$. Similar results were found in aspirin-treated HUVECs.

TNF $\alpha$ treatment increased VE-cadherin expression by $36.9 \% \pm 6.6$ and $28.2 \% \pm 6.0 \%$ at 1 and $9 \mathrm{dyn} / \mathrm{cm}^{2}$, respectively. Ginkgolide B and aspirin reduced TNF $\alpha$-induced VE-cadherin expression at 1 and $9 \mathrm{dyn} / \mathrm{cm}^{2}$. Cx43 expression increased by $20.9 \% \pm 7.1$ and $21.8 \% \pm 5.4 \%$ at 1 and $9 \mathrm{dyn} / \mathrm{cm}^{2}$ in TNF $\alpha$-treated HUVECs, respectively. Both ginkgolide $\mathrm{B}$ and aspirin completely suppressed TNF $\alpha$-induced Cx43 expression at 1 and $9 \mathrm{dyn} / \mathrm{cm}^{2}$. 

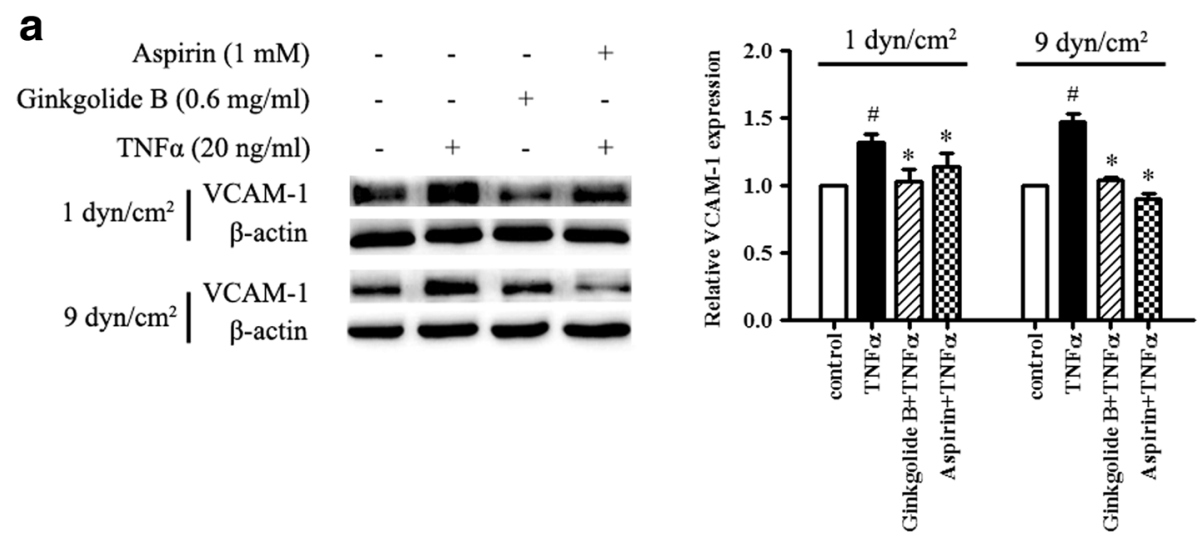

b
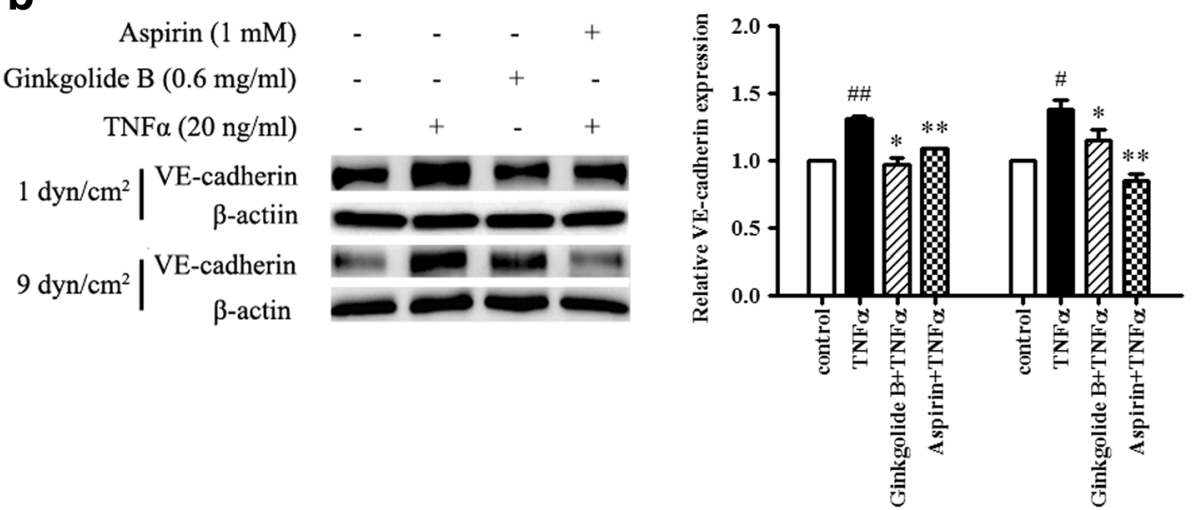

\section{C}
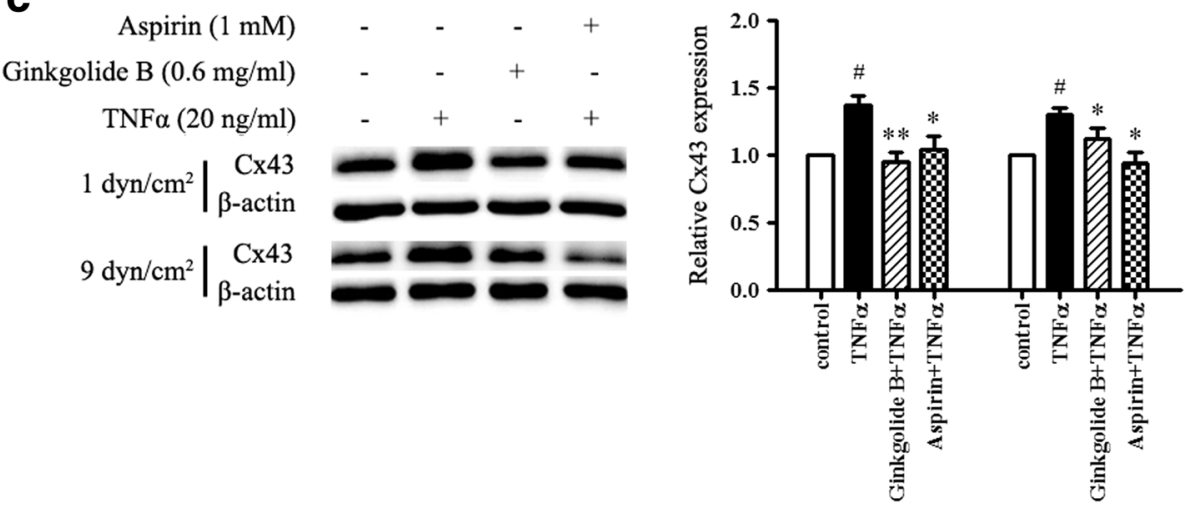

Fig. 2 Ginkgolide B suppressed VCAM-1, VE-cadherin, and Cx43 expression in TNFa-treated HUVECs that presented platelet adhesion under different conditions of laminar shear stress. HUVECs were incubated with ginkgolide B (0.6 mg/ml) or aspirin ( $1 \mathrm{mM})$ for $12 \mathrm{~h}$, and then TNFa $(20 \mathrm{ng} / \mathrm{ml})$ was added for another $2 \mathrm{~h}$. The platelet suspension was then added to the input well at 1 and $9 \mathrm{dyn} / \mathrm{cm}^{2}$ of laminar shear stress for $45 \mathrm{~min}$. Unadhered platelets were removed by the addition of PBS buffer for 2 min. Lysates were then collected by the addition of lysis buffer. Protein expression was analyzed by Western blot. The data were obtained from three independent experiments. a Ginkgolide B inhibited TNFainduced VCAM-1 expression at 1 and $9 \mathrm{dyn} / \mathrm{cm}^{2}$. b Ginkgolide B decreased TNFa-induced VE-cadherin expression at 1 and $9 \mathrm{dyn} / \mathrm{cm}^{2}$. c Ginkgolide B reduced TNFa-induced Cx43 expression at 1 and 9 dyn/ $\mathrm{cm}^{2} .{ }^{\#} p<0.05$, significant difference between TNFa-treated and -untreated HUVECS. ${ }^{* *} p<0.01$, significant difference between TNFa-treated cells and ginkgolide B- and aspirin-treated cells

\section{Discussion}

Platelets, monocytes, and endothelial cells interact in pathological states. Platelets release several inflammatory mediators, such as platelet factor 4 (PF4), regulated on activation, normal T-cell expressed and secreted chemokine (RANTES), P-selectin, and CD40 ligand, to recruit monocytes to the site of damaged endothelial cells [2628]. The adhesion of platelets through the expression of adhesion proteins can also elicit an inflammatory response in endothelial cells [29]. Monocyte adhesion to endothelial cells and enter intima where phagocytosis lipids and transform into macrophage and foam cells 

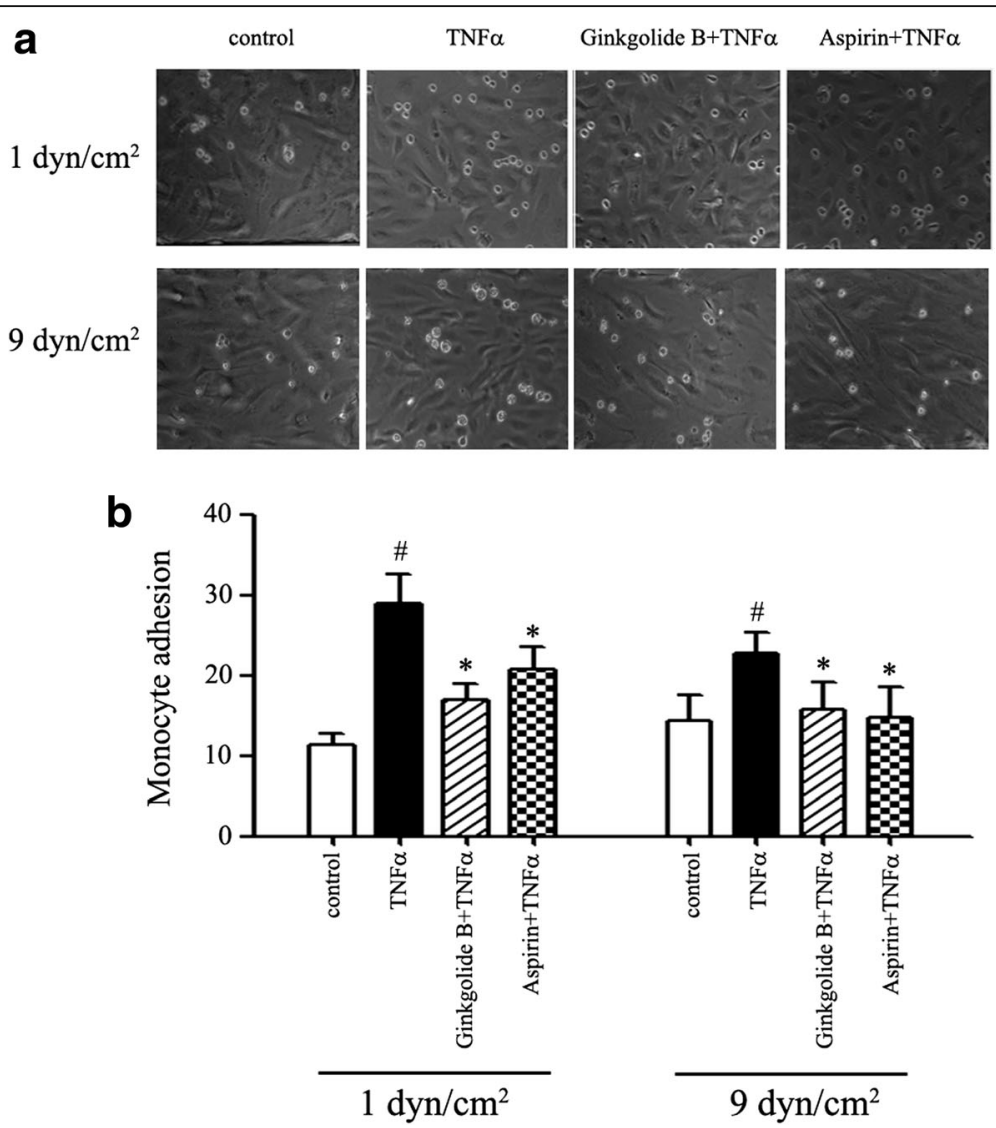

Fig. 3 Ginkgolide B reduced monocyte adhesion to TNFa-treated HUVECs under different conditions of laminar shear stress. HUVECs were incubated with ginkgolide B $(0.6 \mathrm{mg} / \mathrm{ml})$ or aspirin $(1 \mathrm{mM})$ for $12 \mathrm{~h}$, and then TNFa $(20 \mathrm{ng} / \mathrm{ml})$ was added for another $2 \mathrm{~h}$. The monocyte suspension was then added to the input well at 1 and $9 \mathrm{dyn} / \mathrm{cm}^{2}$ of laminar shear stress for $45 \mathrm{~min}$. The data were obtained from three independent experiments. a Ginkgolide B reduced TNFa-induced monocyte adhesion to HUVECs at 1 and 9 dyn/ $\mathrm{cm}^{2}$. $\mathbf{b}$ Monocyte adhesion to HUVECS. ${ }^{\#} p<0.05$, significant difference between TNFa-treated and -untreated HUVECs. ${ }^{*} p<0.01$, significant difference between TNFa-treated cells and ginkgolide B- and aspirin-treated cells

[30-32]. This process is involved in plaque formation in atherosclerosis. Therefore, the inhibition of platelet and monocyte adhesion to endothelial cells might be a strategy for preventing atherosclerosis.

In the present study, we used the Bioflux 1000 microfluidic device to investigate platelet and monocyte adhesion to endothelial cells under different conditions of laminar shear stress. High shear stress in the laminar flow promotes endothelial cell survival and anticoagulation. Low shear stress in the laminar flow promotes endothelial cell proliferation, apoptosis, and coagulation [33]. However, the precise mechanisms by which these processes occur are still unknown. To determine the effects of different conditions of shear stress on the interaction between platelets/monocytes and endothelial cells, two conditions of shear stress were used (1 and $9 \mathrm{dyn} / \mathrm{cm}^{2}$ ). Laminar shear stress at $1 \mathrm{dyn} / \mathrm{cm}^{2}$ reflects a pathological state, and $9 \mathrm{dyn} / \mathrm{cm}^{2}$ reflects a physiological state [34]. Areas of low shear stress in vessels may be linked to endothelial cell dysfunction, reflected by lower nitric oxide and prostacyclin production. The present results showed that the number of platelets that adhered to HUVECs at $1 \mathrm{dyn} / \mathrm{cm}^{2}$ was greater than the number that adhered at $9 \mathrm{dyn} / \mathrm{cm}^{2}$. Monocyte adhesion presented a similar trend. The number of monocytes that adhered to HUVECs at $1 \mathrm{dyn} / \mathrm{cm}^{2}$ was greater than the number that adhered at $9 \mathrm{dyn} / \mathrm{cm}^{2}$. These results support the hypothesis that platelets and monocytes under conditions of low shear stress easily adhere to endothelial cells. We also observed phenotypic changes in endothelial cells under conditions of low and high shear stress. The expression of VCAM-1, VE-cadherin, and Cx43 was not different between 1 and $9 \mathrm{dyn} / \mathrm{cm}^{2}$. This implies that $9 \mathrm{dyn} / \mathrm{cm}^{2}$ of laminar shear stress does not impact TNF $\alpha$-induced VCAM-1, VE-cadherin, or Cx43 expression. Both ginkgolide $\mathrm{B}$ and aspirin exerted protective actions against the expression of these proteins that was induced by TNF $\alpha$ under conditions of laminar shear stress. This is consistent with our previous study, in which increases in VE-cadherin and Cx43 expression 

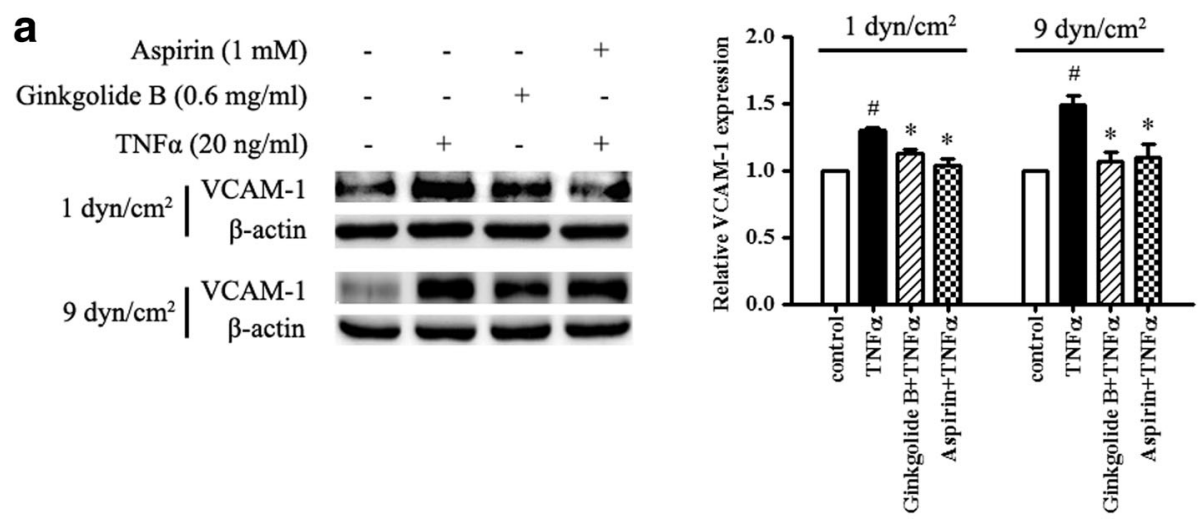

b
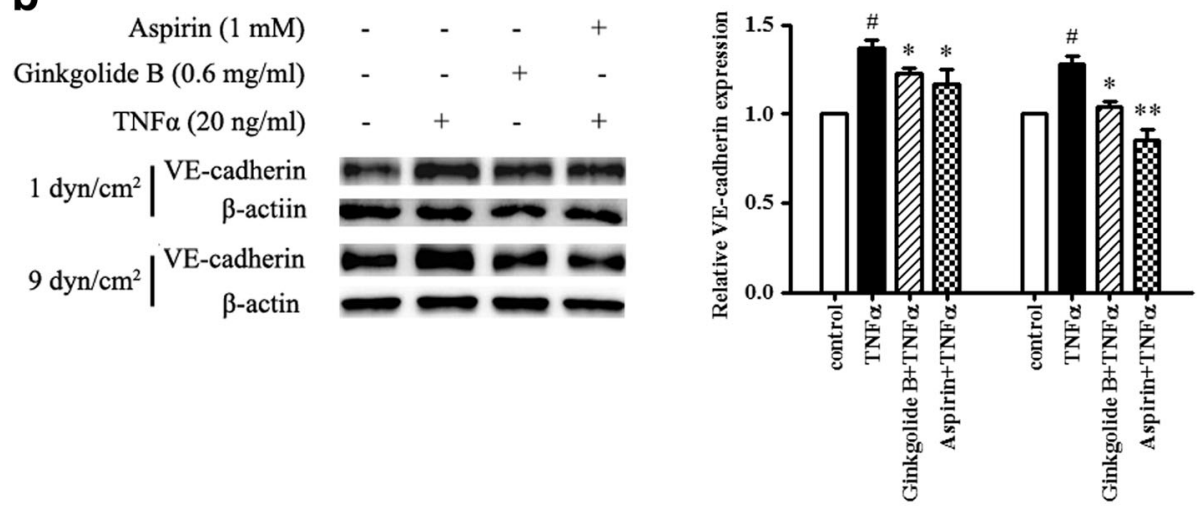

\section{C}
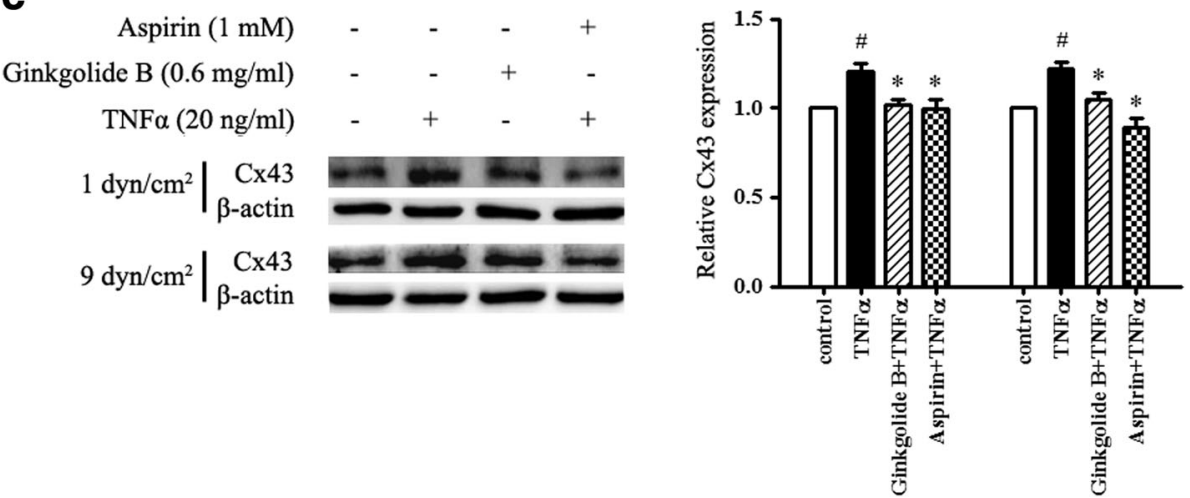

Fig. 4 Ginkgolide B suppressed VCAM-1, VE-cadherin, and Cx43 expression in TNFa-treated HUVECs that presented monocyte adhesion under different conditions of laminar shear stress. HUVECs were incubated with ginkgolide B $(0.6 \mathrm{mg} / \mathrm{ml})$ or aspirin ( $1 \mathrm{mM})$ for $12 \mathrm{~h}$, and then TNFa (20 ng/ml) was added for another $2 \mathrm{~h}$. The monocyte suspension was then added to the input well at 1 and $9 \mathrm{dyn} / \mathrm{cm}^{2}$ of laminar shear stress for $45 \mathrm{~min}$. Unadhered monocytes were removed by the addition of PBS buffer for $2 \mathrm{~min}$. Lysates were then collected by the addition of lysis buffer. Protein expression was analyzed by Western blot. a Ginkgolide B inhibited TNFa-induced VCAM-1 expression at 1 and 9 dyn/ $\mathrm{cm}^{2}$. b Ginkgolide B decreased TNFa-induced VE-cadherin expression at 1 and 9 dyn $/ \mathrm{cm}^{2}$. c Ginkgolide B reduced TNFa-induced Cx43 expression at 1. and $9 \mathrm{dyn} / \mathrm{cm}^{2} .{ }^{\#} p<0.05$, significant difference between TNFa-treated and -untreated HUVECs. ${ }^{*} p<0.05,{ }^{* *} p<0.01$, significant difference between TNFa-treated cells and ginkgolide B- and aspirin-treated cells

were linked to monocyte migration that was induced by ox-LDL. Furthermore, the knockdown of VE-cadherin and $\mathrm{Cx} 43$ gene expression by siRNA decreased the number of monocytes that migrated in ox-LDL-treated HUVECs [14]. This suggests VE-cadherin and Cx43 mediate monocyte migration, and this phenomenon might occur independently of their function at cell junctions. In the present study, platelet and monocyte adhesion decreased under conditions of high shear stress, but the underlying mechanism needs clarification.

Growing evidence has shown the protective action of ginkgolide $\mathrm{B}$ on cardiovascular and nervous system 
diseases. Our previous studies showed that ginkgolide B inhibited platelet aggregation and reduced CD40L, RANTES and PF4 secretion induced by thrombin and collagen. Moreover, ginkgolide B treatment decreased platelet adhesion on aortic plaque in Apo E gene defective mice [20]. Recent a study reported that ginkgolide B promoted microglia/macrophage transferring from inflammatory M1 phenotype to anti-inflammatory phenotype M2 in vivo and in vitro [35]. In recent years Ginkgo biloba extracts have been widely used as a phytomedicine in Europe and in the United States. These studies demonstrated that ginkgolide $\mathrm{B}$ might be a promising drug in clinic application.

\section{Conclusion}

In conclusion, we found that platelet and monocyte adhesion was stronger under conditions of $1 \mathrm{dyn} / \mathrm{cm}^{2}$ of laminar shear stress compared with $9 \mathrm{dyn} / \mathrm{cm}^{2}$. Ginkgolide B inhibited TNF $\alpha$-induced platelet and monocyte adhesion to endothelial cells and attenuated VCAM-1, VE-cadherin, and Cx43 expression under conditions of laminar shear stress. No differences in the expression of these proteins were found between 1 and $9 \mathrm{dyn} / \mathrm{cm}^{2}$. These findings suggest that ginkgolide $B$ might shed light on the treatment of inflammation in atherosclerosis.

\section{Abbreviations}

NF-kB: Nuclear factor kB; TNFa: Tumor necrosis factor a;

EDTA: Ethylenediaminetetraacetic acid; EGTA: Ethylene glycol tetraacetic acid; HUVECs: Human umbilical vein endothelial cells; ox-LDL: Oxidized lowdensity lipoprotein; PMSF: Phenylmethylsulfonyl fluoride; RANTES: Regulated on activation, normal T-cell expressed and secreted chemokine; VCAM-

1: Vascular cell adhesion molecule-1

\section{Acknowledgements}

We thank Dr. Yun You and Dr. Fulong Liao provides Bioflux 1000 facility for the present study. We would like to thank all the participants in the present study. We also thank the funding NSFC for the financial support.

\section{Funding}

This study was funded by National Natural Science Foundation of China (NSFC) (grant numbers 80471051, 81270379, 81070231, and 91649110). The funding agency had no role in the design of the study; in the collection, analyses, or interpretation of data; in the writing of the manuscript; or in the decision to publish the results.

\section{Availability of data and materials}

The datasets used and/or analyzed during the current study are available from the corresponding author on reasonable request. All data generated or analyzed during this study are included in this published article.

\section{Authors' contributions}

Conceived and designed the experiments: RMQ and YY. Performed the experiments: JS, MZ, YYZ, BDC, and HG. Analyzed the data: MZ and JS. Wrote the paper: RMQ. All author reviewed and approved the manuscript.

\section{Ethics approval and consent to participate}

Blood was collected from healthy donors who provided written informed consent. The experiments were conducted according to the principles of the Declaration of Helsinki. This study was approved by the Ethics Committee of the Beijing Institute of Geriatrics (no. 2015026).
Consent for publication

Not applicable.

Competing interests

The authors declare that they have no competing interests.

\section{Publisher's Note}

Springer Nature remains neutral with regard to jurisdictional claims in published maps and institutional affiliations.

\section{Author details}

${ }^{1} \mathrm{MOH}$ Key Laboratory of Geriatrics, Beijing Hospital, National Center of Gerontology, Beijing, China. ${ }^{2}$ Graduate School of Peking Union Medical College, Chinese Academy of Medical Sciences, Beijing, China. ${ }^{3}$ Institute of Chinese Materia Medica, China Academy of Chinese Medical Sciences, Beijing, China.

Received: 21 March 2018 Accepted: 11 July 2018

Published online: 20 July 2018

\section{References}

1. Nakajima H, Yamamoto K, Agarwala S, Terai K, Fukui H, Fukuhara S, et al. Flow-dependent endothelial YAP regulation contributes to vessel maintenance. Dev Cell 2017:40:523-536.

2. Urschel K, Garlichs CD, Daniel WG, Cicha I. VEGFR2 signalling contributes to increased endothelial susceptibility to TNF-alpha under chronic non-uniform shear stress. Atherosclerosis. 2011;219:499-509.

3. Johnson BD, Mather KJ, Wallace JP. Mechanotransduction of shear in the endothelium: basic studies and clinical implications. Vasc Med. 2011:16:365-77.

4. Paszkowiak JJ, Dardik A. Arterial wall shear stress: observations from the bench to the bedside. Vasc Endovasc Surg. 2003:37:47-57.

5. Schuler D, Sansone R, Freudenberger T, Rodriguez-Mateos A, Weber G, Momma TY, et al. Measurement of endothelium-dependent vasodilation in mice--brief report. Arterioscler Thromb Vasc Biol. 2014;34:2651-2657.

6. Inaba H, Takeshita K, Uchida Y, Hayashi M, Okumura T, Hirashiki A, et al. Recovery of flow-mediated vasodilatation after repetitive measurements is involved in early vascular impairment: comparison with indices of vascular tone. PLoS One 2014;9:e83977.

7. Verbeke FH, Pannier B, Guérin AP, Boutouyrie P, Laurent S, London GM. Flow-mediated vasodilation in end-stage renal disease. Clin J Am Soc Nephrol. 2011;6:2009-15.

8. Okorie UM, Denney WS, Chatterjee MS, Neeves KB, Diamond SL. Determination of surface tissue factor thresholds that trigger coagulation at venous and arterial shear rates: amplification of $100 \mathrm{fM}$ circulating tissue factor requires flow. Blood. 2008;111:3507-13.

9. Ahmadsei M, Lievens D, Weber C, Von HP, Gerdes N. Immune-mediated and lipid-mediated platelet function in atherosclerosis. Curr Opin Lipidol. 2015; 26:438-48.

10. Soehnlein O. Monocytes chat with atherosclerotic lesions. Arterioscler Thromb Vasc Biol. 2016;36:1720-1.

11. Badimon L, Suades R, Fuentes E, Palomo I, Padró T. Role of platelet-derived microvesicles as crosstalk mediators in Atherothrombosis and future pharmacology targets: a link between inflammation, atherosclerosis, and thrombosis. Front Pharmacol. 2016;7:293.

12. Gavard J. Endothelial permeability and VE-cadherin: a wacky comradeship. Cell Adhes Migr. 2013;7:455-61.

13. Corada M, Liao F, Lindgren M, Lampugnani MG, Breviario F, Frank R, et al. Monoclonal antibodies directed to different regions of vascular endothelial cadherin extracellular domain affect adhesion and clustering of the protein and modulate endothelial permeability. Blood 2001;97:1679-1684.

14. Liu X, Sun W, Zhao Y, Chen B, Wu W, Li B, et al. Ginkgolide B inhibits JAM-A $\mathrm{C} \times 43$, and VE-cadherin expression and reduces monocyte transmigration in oxidized LDL-stimulated human umbilical vein endothelial cells. Oxidative Med Cell Longev 2015;2015:907926

15. Cheng JC, Chang HM, Fang L, Sun YP, Leung PC. TGF- $\beta 1$ up-regulates connexin43 expression: a potential mechanism for human trophoblast cell differentiation. J Cell Physiol. 2015;230:1558-66.

16. Laird DW. Syndromic and non-syndromic disease-linked Cx43 mutations. FEBS Lett. 2014;588:1339-48. 
17. Ghosh S, Kumar A, Chandna S. Connexin-43 downregulation in G2/M phase enriched tumour cells causes extensive low-dose hyper-radiosensitivity (HRS) associated with mitochondrial apoptotic events. Cancer Lett. 2015;363:46-59.

18. Chin-Feng H, Hsia-Fen H, Wei-Kung T, Thung-Lip L, Yu-Feng W, Kwan-Lih H, et al. Glossogyne tenuifolia extract inhibits TNF-a-induced expression of adhesion molecules in human umbilical vein endothelial cells via blocking the NF-kB signaling pathway. Molecules 2015;20:16908-16923.

19. Hu L, Chen $Z$, Xie Y, Jiang $Y$, Zhen $H$. New products from alkali fusion of Ginkgolides a and B. J Asian Nat Prod Res. 2000;2:103-10.

20. Liu X, Zhao G, Yan Y, Bao L, Chen B, Qi R. Ginkgolide B reduces atherogenesis and vascular inflammation in ApoE(-/-) mice. PLoS One. 2012; $7: 36237$.

21. Zhang S, Chen B, Wu W, Bao L, Qi R. Ginkgolide B reduces inflammatory protein expression in oxidized low-density lipoprotein-stimulated human vascular endothelial cells. J Cardiovasc Pharmacol. 2011:57:721-7.

22. Reiss C, Mindukshev I, Bischoff V, Subramanian H, Kehrer L, Friebe A, et al. The SGC stimulator riociguat inhibits platelet function in washed platelets but not in whole blood. Br J Pharmacol 2015; 172:5199-5210.

23. Scipione CA, Sayegh SE, Romagnuolo R, Tsimikas S, Marcovina SM, Boffa MB, et al. Mechanistic insights into Lp(a)-induced IL-8 expression: a role for oxidized phospholipid modification of apo(a). J Lipid Res 2015;56:2273-2285.

24. Qin WD, Mi SH, Li C, Wang GX, Zhang JN, Wang H, et al. Low shear stress induced HMGB1 translocation and release via PECAM-1/PARP-1 pathway to induce inflammation response. PLoS One 2015;10:e0120586.

25. Sato M, Levesque MJ, Nerem RM. Micropipette aspiration of cultured bovine aortic endothelial cells exposed to shear stress. Arteriosclerosis. 1987;7:276-86.

26. Woller G, Brandt E, Mittelstädt J, Rybakowski C, Petersen F. Platelet factor 4/ CXCL4-stimulated human monocytes induce apoptosis in endothelial cells by the release of oxygen radicals. J Leukoc Biol. 2008;83:936-45.

27. Von HP, Weber KS, Huo Y, Proudfoot AE, Nelson PJ, Ley K, et al. RANTES deposition by platelets triggers monocyte arrest on inflamed and atherosclerotic endothelium. Circulation 2001;103:1772-1777.

28. Lievens D, Zernecke A, Seijkens T, Soehnlein O, Beckers L, Munnix IC, et al. Platelet CD40L mediates thrombotic and inflammatory processes in atherosclerosis. Blood 2010;116:4317-4327.

29. Blann AD, Nadar SK, Lip GY. The adhesion molecule P-selectin and cardiovascular disease. Eur Heart J. 2003:24:2166-79.

30. Hilgendorf I, Swirski FK, Robbins CS. Monocyte fate in atherosclerosis. Arterioscler Thromb Vasc Biol. 2015:35:272-9.

31. Plotkin JD, Elias MG, Dellinger AL, Kepley CL. NF-KB inhibitors that prevent foam cell formation and atherosclerotic plaque accumulation. Nanomedicine. 2017;13:2037-48.

32. Fong GH. Potential contributions of intimal and plaque hypoxia to atherosclerosis. Curr Atheroscler Rep. 2015;17:1-10.

33. Cunningham KS, Gotlieb Al. The role of shear stress in the pathogenesis of atherosclerosis. Lab Investig. 2005;85:9-23.

34. Stepp DW, Nishikawa Y, Chilian WM. Regulation of shear stress in the canine coronary microcirculation. Circulation. 1999;100:1555-61.

35. Shu ZM, Shu XD, Li HQ, Sun Y, Shan H, Sun XY, et al: Ginkgolide B protects against ischemic stroke via modulating microglia polarization in mice. CNS Neurosci Ther 2016;22:729-739.

Ready to submit your research? Choose BMC and benefit from:

- fast, convenient online submission

- thorough peer review by experienced researchers in your field

- rapid publication on acceptance

- support for research data, including large and complex data types

- gold Open Access which fosters wider collaboration and increased citations

- maximum visibility for your research: over $100 \mathrm{M}$ website views per year

At BMC, research is always in progress.

Learn more biomedcentral.com/submissions 